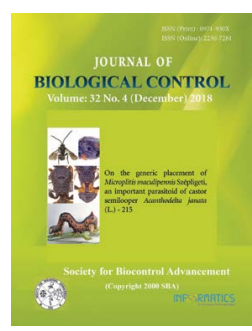

\title{
Natural enemies of whitefly, Bemisia tabaci (Gennadius) on cotton in Punjab, India
}

\author{
K. S. SANGHA*, P. S. SHERA, SUDHENDU SHARMA and RABINDER KAUR \\ Department of Entomology, Punjab Agricultural University, Ludhiana - 141004, Punjab, India \\ *Corresponding author Email: kssangha@pau.edu
}

\begin{abstract}
The whitefly, Bemisia tabaci (Gennadius) is a polyphagous pest, widely distributed in diverse agroecosystems across the globe. Several bioagents including predators and parasitoids from diverse groups have been recorded against whitefly worldwide. A field survey was conducted during 2016 and 2017 in different cotton growing districts of Punjab to record the natural enemies associated with whitefly. Sixteen species of natural enemies were recorded, including 7 species of insect predators; 2 species of parasitoids and 7 species of spiders. Coccinella septempunctata Linneaus, Cheilomenes sexmaculata (Fabricius) and Brumoides suturalis (Fabricius), Serangium parcesetosum Sicard, Chrysoperla zastrowi sillemi (Esben-Peterson), Zanchius breviceps (Wagner), Geocoris sp. and spiders were most commonly recorded predators. Out of these, Chrysoperla was the predominant species. Encarsia lutea (Masi) and Encarsia sophia (Girault \& Dodd) were the two parasitoids that emerged from whitefly pupae. The mean parasitization of whitefly by Encarsia spp. in different cotton growing areas of Punjab was 5.20 per cent (range $=1.5$ to $9.1 \%)$.
\end{abstract}

KEY WORDS: Cotton, parasitoid, predator, whitefly

(Article chronicle: Received: 07-06-2018; Revised: 16-11-2018; Accepted: 15-12-2018)

Cotton is an important commercial and industrial fibre crop of India which played a key role in economic and social development of the country. Area wise, India ranked first in global scenario contributing about 37 per cent of the world cotton area with a production of 37.7 million bales (170 kg lint/bale) and average lint yield of $524 \mathrm{~kg} \mathrm{ha}^{-1}$ in 2017-18 (Anonymous, 2018). The successful adoption of genetically modified cotton with genes from soil inhabiting spore forming bacterium, Bacillus thuringiensis Berliner has changed the entire pest scenario in the country. The pest status of bollworms and leaf feeding insects has declined, but sap feeders, including whitefly, Bemisia tabaci (Gennadiaus), leafhopper, Amrasca biguttula biguttula (Ishida), mealybug, Phenacoccus solenopsis Tinsley, thrips, Thrips tabaci (Lindemann), aphid, Aphis gossypii (Glover) and mirid, Creontiades biseratense (Distant) are emerging as serious pests (Mann et al., 2010; Kumar et al., 2015).

The whitefly, B. tabaci (Hemiptera: Aleyrodidae) is a destructive pest of many vegetable, horticultural, ornamental and agricultural crops in tropical and subtropical countries of the world (Oliveria et al., 2001; Simmons et al., 2008). It feeds on more than 900 diverse host plants, including species of economic importance belonging to the 63 families (Perring, 2001; Buxton, 2005). It is a phloem-sucking insect, the nymphs and adults of which cause damage by sucking cell sap. The development of sooty mould on honey dew secreted by them invariably affects photosynthesis of plants. Moreover, it also transmits more than 111 plant viruses (Jones, 2003) including cotton leaf curl virus $(\mathrm{CLCuV})$ in American cotton (Hassan et al., 2016). Several bioagents from diverse groups have been recorded against whitefly across India (Rao et al., 1989; Natarajan 1990; Kedar et al., 2014; Boda and Ilyas 2017; Rawal et al., 2017). Huge populations of whiteflies were recorded during 2015 in Punjab, Haryana and Rajasthan leading to considerable economic losses to the farmers. This epidemic infestation resulted in large reduction in area under cotton in the subsequent years. It is therefore, essential that we reestablish the diversity of native natural enemies. Keeping in view economic importance of this pest, surveys were undertaken to explore natural enemy fauna associated with whitefly in cotton agro-ecosystem under Punjab conditions.

Regular surveys were conducted in cotton growing areas of Punjab (Fazilka, Bathinda, Mansa and Muktsar districts) during kharif seasons, 2016 and 2017 to record natural enemies associated with whitefly on cotton crop. For sampling, each 
cotton field was divided into 4 equal plots. In each plot, 25 plants were selected at random for recording observations on natural enemy fauna. Each plant (as a whole) was visually examined for recording population of different predators, i.e. coccinellids, chrysopids, mirids and spiders. The collected predators were identified from the specimens available in the Department of Entomology, Punjab Agricultural University, Ludhiana. The samples of green bug were sent to Professor C.A. Viraktamath, Emeritus Scientist, Department of Entomology, University of Agricultural Sciences, Bengaluru for identification up to species level.

For parasitoids, twenty cotton leaves infested with immature stages were collected from each field during survey andbroughttotheBiocontrollaboratorytorecordparasitization. Assessment of parasitism (\%) was determined based on the number of parasitized nymphs as against un-parasitized ones in the host leaves. The leaves with parasitized nymphs were kept in glass jars covered with muslin cloth for the emergence of parasitoids. The emerging parasitoids were collected using aspirator and preserved in vials containing 70 per cent ethanol. The specimen of parasitoids were got identified from Dr Mohammad Hayat, Aligarh Muslim University, Aligarh.

Natural enemy fauna comprising 9 species of insects under 5 families; 7 species of arachnids in 4 families constituting a total of 16 species were recorded from the cotton field during the study. The collected insect fauna comprised of 7 species of predators and 2 species of parasitoids. The insect predators included Coccinella septempunctata Linneaus, Cheilomenes sexmaculata (Fabricius), Brumoides suturalis (Fabricius), Serangium parcesetosum Sicard, Chrysoperla zastrowi sillemi (Esben-Peterson), Zanchius breviceps (Wagner) and Geocoris sp. (Table 1). The collected spider population included Neoscona sp., Argiope sp., Oxyopes sp., Thomisus sp., Runcinia sp., Hyllus sp. and Chrysilla sp. In 2016, population of Chrysoperla was low during $1^{\text {st }}$ week of June and attained its peak in the $4^{\text {th }}$ week of June (Fig. 1). During 2017 , the population of Chrysoperla was maximum till $3^{\text {rd }}$ week of July and declined thereafter. The peak population of spiders was

Table 1. List of arthropod predators and parasitoids recorded on cotton crop in Punjab

\begin{tabular}{|c|c|c|}
\hline Natural enemies & Family & Order \\
\hline \multicolumn{3}{|l|}{ Insect Predators } \\
\hline $\begin{array}{l}\text { Coccinella septempunctata } \\
\text { Linneaus }\end{array}$ & Coccinellidae & Coleoptera \\
\hline $\begin{array}{l}\text { Cheilomenes sexmaculata } \\
\text { (Fabricius) }\end{array}$ & Coccinellidae & Coleoptera \\
\hline $\begin{array}{l}\text { Brumoides suturalis } \\
\text { (Fabricius) }\end{array}$ & Coccinellidae & Coleoptera \\
\hline $\begin{array}{l}\text { Serangium parcesetosum } \\
\text { Sicard }\end{array}$ & Coccinellidae & Coleoptera \\
\hline $\begin{array}{l}\text { Chrysoperla zastrowi } \\
\text { sillemi (Esben-Peterson) }\end{array}$ & Chrysopidae & Neuroptera \\
\hline $\begin{array}{l}\text { Zanchius breviceps } \\
\text { (Wagner) }\end{array}$ & Miridae & Hemiptera \\
\hline Geocoris sp. & Geocoridae & Hemiptera \\
\hline \multicolumn{3}{|l|}{ Spiders } \\
\hline Neoscona sp. & Araneidae & Araneae \\
\hline Argiope sp. & Araneidae & Araneae \\
\hline Oxyopes sp. & Oxyopidae & Araneae \\
\hline Thomisus sp. & Thomosidae & Araneae \\
\hline Runcinia sp. & Thomisidae & Araneae \\
\hline Hyllus sp. & Salticidae & Araneae \\
\hline Chrysilla sp. & Salticidae & Araneae \\
\hline \multicolumn{3}{|l|}{ Parasitoids } \\
\hline Encarsia lutea (Masi) & Aphelinidae & Hymenoptera \\
\hline $\begin{array}{l}\text { Encarsia sophia } \\
\text { (Girault \& Dodd) }\end{array}$ & Aphelinidae & Hymenoptera \\
\hline
\end{tabular}

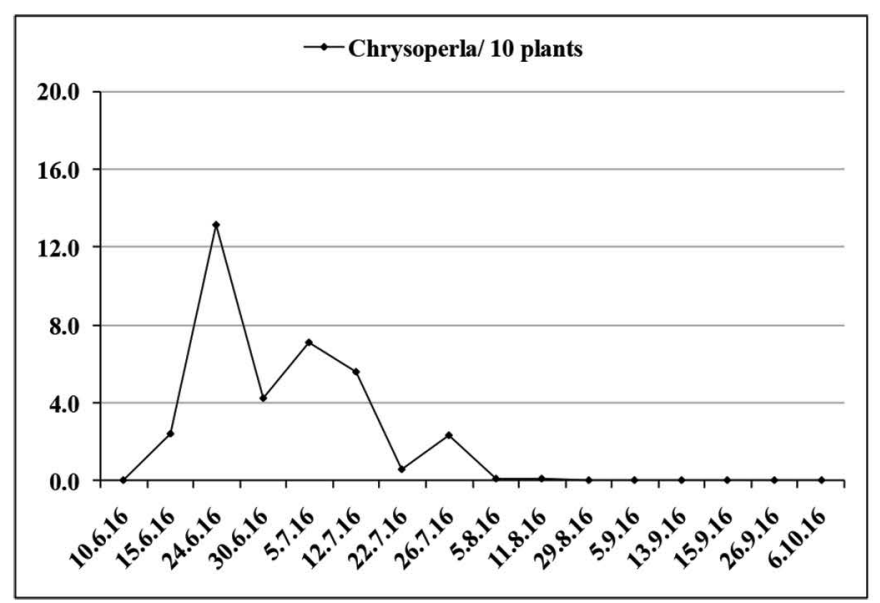

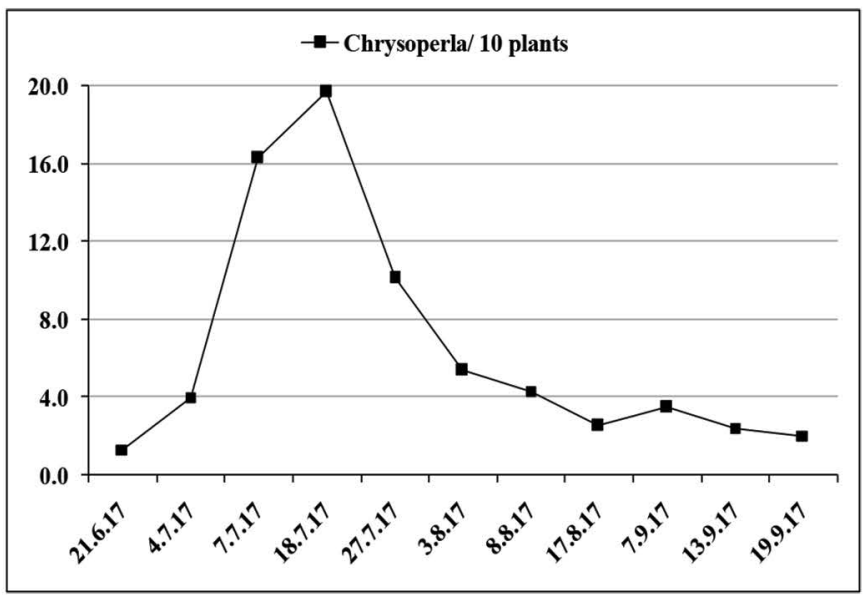

Fig. 1. Population trends of Chrysoperla in cotton growing areas of Punjab during 2016 and 2017. 
recorded during $3^{\text {rd }}$ week of July and $4^{\text {th }}$ week of August during 2016 and 2017, respectively (Fig. 2). The activity of chrysopids, coccinellids, spiders and other predators have been reported in cotton and other cropping systems by many workers worldwide (Purohit et al., 2006; Kutuk et al., 2008; Simmons and Rabou 2007; Kedar et al., 2014). Further, these natural enemies have been reported to contribute significantly to reduce the population of $B$. tabaci in cotton and several other crops (Naranjo and Ellsworth, 2005; Naranjo et al., 2009).

The parasitoid species observed parasitizing $B$. tabaci in the field were Encarsia lutea (Masi) (Hymenoptera: Aphelinidae) and E. sophia (Girault \& Dodd) (Hymenoptera: Aphelinidae) that emerged from whitefly pupae. Out of 6349 nymphs observed, 330 were found to be parasitized (Table 2). The mean parasitization of whitefly by Encarsia spp. in different cotton growing areas of Punjab was 5.20 per cent. The maximum parasitization (9.12\%) was observed in Mansa population followed by whitefly population from Ludhiana $(6.49 \%)$. The minimum parasitization was recorded in Faridkot population (1.49\%). Encarsia, the aphilinid parasitoids, are of worldwide distribution and have been reported to parasitize many whitefly species including B. tabaci (Gerling et al., 2001; Oliveira et al., 2003; Torres et al., 2014). The parasitization of B. tabaci by E. lutea has also been reported in Haryana on different crops like okra, cotton, soybean, ricebean and egg plant (Sharma et al., 2003; Kedar et al., 2014)

The present investigations provide information on the predators and parasitoids functioning against whitefly in cotton agro-ecosystem under Punjab conditions. The insecticide applications to curb whitefly menace should be planned considering pest scouting and injury levels to conserve these natural enemy populations. Further work is needed to explore the possibility of associated arthropod fauna to facilitate a biologically-based integrated pest management in cotton ecosystem.

\section{ACKNOWLEDGEMENTS}

The authors are thankful to Professor C. A. Viraktamath, University of Agricultural Sciences, Bengaluru, Dr. Mohammad Hayat, Aligarh Muslim University, Aligarh and Dr. Sampath Kumar, ICAR-National Bureau of Agricultural Insect Resources, Bengaluru for identification of mirid, aphelinids and spiders, respectively.

Table 2. Parasitization of whitefly by Encarsia spp. on cotton in Punjab during 2017

\begin{tabular}{|l|c|c|c|}
\hline Districts & $\begin{array}{c}\text { Number } \\
\text { of whitefly } \\
\text { nymphs } \\
\text { observed }\end{array}$ & $\begin{array}{c}\text { Number of } \\
\text { parasitized } \\
\text { nymphs }\end{array}$ & $\begin{array}{c}\text { Per cent } \\
\text { parasitization }\end{array}$ \\
\hline Mansa & 2302 & 210 & 9.12 \\
\hline Muktsar & 1522 & 36 & 2.36 \\
\hline Bathinda & 952 & 29 & 3.05 \\
\hline Faridkot & 605 & 9 & 1.49 \\
\hline Ludhiana & 462 & 30 & 6.49 \\
\hline Fazilka & 389 & 16 & 4.11 \\
\hline Total/Mean & 6349 & 330 & 5.20 \\
\hline
\end{tabular}

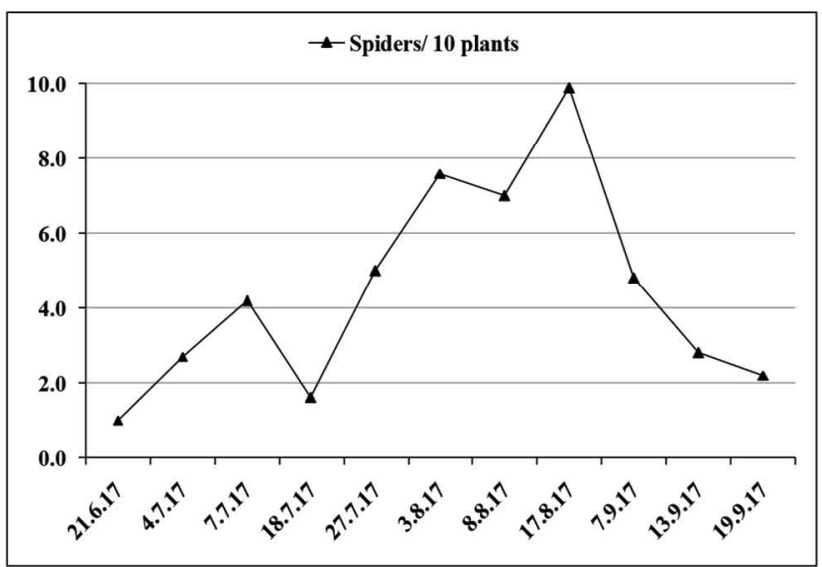

Fig. 2. Population trends of spiders in cotton growing areas of Punjab during 2016 and 2017. 


\section{REFERENCES}

Anonymous 2018. Annual Report 2017-18. All India Coordinated Cotton Improvement Project. Central Institute of Cotton Research, Regional Station Coimbatore.

Boda V, Ilyas M. 2017. Population dynamics of sucking pests of Bt cotton and their correlation with abiotic factors. Bull Env Pharmacol Life Sci. 6: 167-171

Buxton J. 2005. Control of whiteflies on protected ornamental crops. Factsheet 14/05. Horticultural Development Council in coop. with DEFRA. Bradbourne House, UK

Gerling D, Alomar O, Arno J 2001. Biological control of Bemisia tabaci using predators and parasitoids. Crop Prot. 20: 779-799. https://doi.org/10.1016/S02612194(01)00111-9

Hassan F, Qayyum A, M Waqas MA, Hassan M, Rehman MA, Shoaib M, Shehzad M, Ahmad S, Ahmad L, Arshad M. 2016. Cotton leafcurl virus (CLCuV) disease in Pakistan: A critical review. Appl Sci Bus Econ. 3: 8-14.

Jones DR. 2003. Plant viruses transmitted by whiteflies. Eur J Pl Path. 109: 95-219. https://oi. org/10.1023/A:1022846630513

Kedar SC, Saini RK, Kumaranag KM, Sharma SS. 2014. Record of natural enemies of whitefly, Bemisia tabaci (Gennadius) (Hemiptera: Aleyrodidae) in some cultivated crops in Haryana J Biopest 7: 57-59.

Kutuk H, Yigit A, Alaoglu O. 2008. The effect of season on the levels of predation by the ladybird Serangium parcesetosum Sicard (Coleoptera: Coccinellidae) on the cotton whitefly Bemisia tabaci (Genn.) (Homoptera: Aleyrodidae), a serious pest of eggplants. J Pest Sci. 81: 207-212. https://doi.org/10.1007/s10340-008-0207-z

Kumar V, Dhawan AK and Shera PS. 2015. Transgenic cotton in India: ten years and beyond. pp. 202-227. In: Singh B, Arora R and Gosal S S (Eds.). Biological and Molecular Approaches in Pest management. Scientific Publishers, Jodhpur,

Mann RS, Gill RS, Dhawan AK, Shera PS. 2010. Relative abundance and damage by target and non target insects on Bollgard and Bollgard II cotton cultivars. Crop Prot. 29: 793-801. https://doi.org/10.1016/j.cropro.2010.04.006

Naranjo SE, Ca-as L, Ellsworth PC. 2009. Mortality and population dynamics of Bemisia tabaci within a multi-crop system. pp. 202-207. In: Mason, P.G., Gillespie, D.R., Vincent, C. (Eds.), Proceedings of the Third International Symposium on Biological Control of Arthropods. Christchurch, New Zealand. USDA Forest Service, FHTET.

Naranjo SE, Ellsworth PC. 2005. Mortality dynamics and population regulation in Bemisia tabaci. Entomol Exp Appl. 116: 93-108. https://doi.org/10.1111/j.1570-7458.2005.00297.x

Natarajan K. 1990. Natural enemies of Bemisia tabaci Gennadius and effect of insecticides on their activity. J Biol Control 4: 86-88.

Oliveira MRV, Amancio E, Laumann RA, Gomes LO. 2003. Natural enemies of Bemisia tabaci (Gennadius) B biotype and Trialeurodes vaporariorum (Westwood) (Hemiptera: Aleyrodidae) in Brasilia, DF. Neotrop Entomol. 32: 151-154. https://doi.org/10.1590/S1519$566 \times 2003000100023$

Perring TM. 2001. The Bemisia tabaci species complex. Crop Prot. 20: 725-737. https://doi.org/10.1016/S02612194(01)00109-0

Purohit D, Ameta OP, Sarangdevot SS. 2006. Seasonal incidence of major insect pests of cotton and their natural enemies. Pestology 30: 24-29.

Rao NV, Reddy AS, Rao KT. 1989. Natural enemies of cotton whitefly, Bemisia tabaci Gennadius in relation to host population and weather factors. J Biol Control. 3: $0-12$.

Rawal R, Dahiya KK, Lal R, Kumar A. 2017. Population dynamics of natural enemies on bt / non bt cotton and their correlation with weather parameters. J App Nat Sci. 9: $2360-2365$.

Sharma SS, Ram P, Batra GR and Jaglan RS. 2003. Parasitization of whitefly, Bemisia tabaci (Gennadius) by Encarsia lutea (Masi) on different crops. Ann Biol. 19: 103-104. 
Simmons, AM and Abd-Rabou S. 2007. Survey of natural enemies of the sweetpotato whitefly (Hemiptera: Aleyrodidae) in ten vegetable crops in Egypt. J Agric Urban Entomol. 24: 137-145. https://doi. org/10.3954/1523-5475-24.3.137

Simmons AM, Harrison HF, Ling KS. 2008. Forty-nine new host plant species for Bemisia tabaci (Hemiptera: Aleyrodidae). Entomol Sci. 11: 385-390.
Torres LC, Lourencao AL, Costa VA, Souza B, Costa, MB and Tanque RL. 2014. Records of natural enemies of Bemisia tabaci (Genn.) (Hemiptera: Aleyrodidae) Biotype B in Brazil. Neotrop Entomol. 43: 189-191. https://doi.org/10.1007/s13744-013-0188-3 